\title{
NATURAL GEOGRAPHICAL TOURISM ATTRACTIONS OF PRENJ MOUNTAIN
}

\author{
Emir Temimović ${ }^{48}$ \\ Amra Banda ${ }^{49}$ \\ Haris Jahic s0 $^{50}$ \\ Ševkija Okeric ${ }^{51}$
}

\begin{abstract}
Prenj mountain is located in the southern part of Bosnia and Herzegovina, in the area of the high karst of Bosnia and Herzegovina. Administratively, it belongs to the municipalities of Konjic, Mostar and Jablanica. Geological, geomorphological and biological diversity identify this area as a representative example in Bosnia and Herzegovina. Magnificent landscapes, exceptional relief characteristics, specific karst areas, glaciation marks, marked hiking trails, excursion sites, numerous endemic species, etc. present potential tourist attractions for the development of mountain, alpinistic and excursion tourism, as well as the stay of scientific expeditions and field research. Along with the favorable traffic-geographical position and the richness of tourist attractions, Prenj has been recently established as a tourist destination, of mainly adventurous tourism, and in 2012 this mountain was chosen as the best destination for mountain biking according to National Geographic. Bike park Prenj consist of $360 \mathrm{~km}$ of mapped and fieldmarked forest and uncategorized trails intended primarily for cycling but also for other types of recreation and sports. Via Dinarica, an adventure and hiking path that connects tourist attractions in seven countries (through which the mountain range of the Dinaric Alps stretches from Slovenia to Albania), has also contributed to the development of this tourism type. The White Trail (Bijela staza) represents the main path that stretches along the entire length of the Via Dinarica and links the mountains of Prenj and Čvrsnica in the research area. This paper presents geographical analysis of the natural segment of Prenj mountain tourism attraction base and gives a brief overview of tourism development from the aspect of adventure tourism.
\end{abstract}

Keywords: Prenj, tourist attractions, natural geographical sights, mountain tourism, adventure tourism, Via Dinarica.

\section{INTRODUCTION}

In general, it can be said that the mountainous areas of Herzegovina-Neretva Canton represent a great potential for the development of almost all tourist activities related to

\footnotetext{
${ }^{48}$ Associate Professor, Department of Geography, Faculty of Science, University of Sarajevo, emirtemimovic@yahoo.com

${ }^{49}$ Senior Teaching Assistant, Department of Geography, Faculty of Science, University of Sarajevo, amra.banda@pmf.unsa.ba

${ }^{50}$ Assistant Professor, Department of Geography, Faculty of Science, University of Sarajevo, haris-jahic@hotmail.com

${ }^{51}$ Assistant Professor, Department of Geography, Faculty of Science, University of Sarajevo okeric@serda.ba
} 
mountain areas. This fact applies especially to the Prenj mountain. Beautiful landscapes, marked hiking trails, steep cliffs, mountain springs, clean air, icebergs etc. represent the attraction base for tourist valorisation of the mentioned geographic elements for the development of mountain tourism. Karst terrain and glaciation marks, represent an attraction for scientific expeditions and field research. Slopes between $25^{\circ}$ - $45^{\circ}$ with enough snow cover represent an attraction for the development of ski tourism. It is important to note that the features of the mountain relief, as tourist attractions, cannot be analysed separately without other natural and social elements of the geographical environment, especially climatic and hydrographic characteristics, as well as potential accommodation capacities and traffic infrastructure.

The most common types of tourist valorisation of mountain areas are: hiking and other recreational activities, adventure activities on wild waters and recreation on the snow. Hiking will allow tourists to enjoy the aesthetic uniqueness of mountain landscapes and gain new experiences in observing mountain flora and fauna. The specific scenarios of walking in the mountains can be very different depending on the season, and this kind of tourist valorisation can be a particularly important source of income in the summer season for areas that are generally dependent on snow related tourist activities. Adventurous activities include cycling, mountain biking, quad biking, horse riding, and less frequent ice climbing, skating and paragliding. Recreational activities on wild waters include canoeing, sailing, windsurfing, kitesurfing, kayaking, rafting and freshwater fishing. Such tourist activities, though related to hydrographic objects, can be part of tourist offer in mountainous areas. Snow recreation activities include cross country skiing, alpine skiing, heliport, snowboarding, sledding, bob, biathlon, etc. Such recreation is mostly limited to higher mountainous areas in a snowy winter tourist season. (Charters, Saxon, 2007)

\section{GEOGRAPHICAL POSITION}

Prenj mountain is located in the southern part of Bosnia and Herzegovina, in the area of the high karst of Bosnia and Herzegovina (Fig. 1). Massif Prenj is a part of the high karst zone of the Outer Dinarides of Bosnia and Herzegovina (Lepirica, 2008). It is bounded by Neretva river valley from Glavatičevo to Bijelo Polje near Mostar, and on the south-east by mountain ranges of Velež (1969 m), Crvanj (1921 m) and Visočica (1964 m). Administratively, it belongs to the municipalities of Konjic, Mostar and Jablanica and it is often called „Heart of Herzegovina“. It is surrounded by natural and artificial lakes Boračko, Jablaničko, Grabovičko, Salakovac and rivers Neretva, Ljuta, Neretvica, Bijela and Drežanka. In the foothill of Prenj are three cities Konjic, Jablanica and Mostar.

Prenj has relatively good traffic connections; in addition to the M-17 highway, there are many forest paths leading to mountain valleys. Most popular paths are from Konjic via Borak to Ruišta, $35 \mathrm{~km}$ long (Borci - Ruišta $22 \mathrm{~km}$ ), then from Konjic via Rapca to the Tisovica valley $(25 \mathrm{~km})$ and from Konjic via Borak to the top of Borašnica $(25 \mathrm{~km})$. In 
the mountainous areas of Herzegovina-Neretva Canton, especially on Prenj and Boračko Lake there is a large number of accommodation facilities with 1231 beds among which 10 mountain lodges.

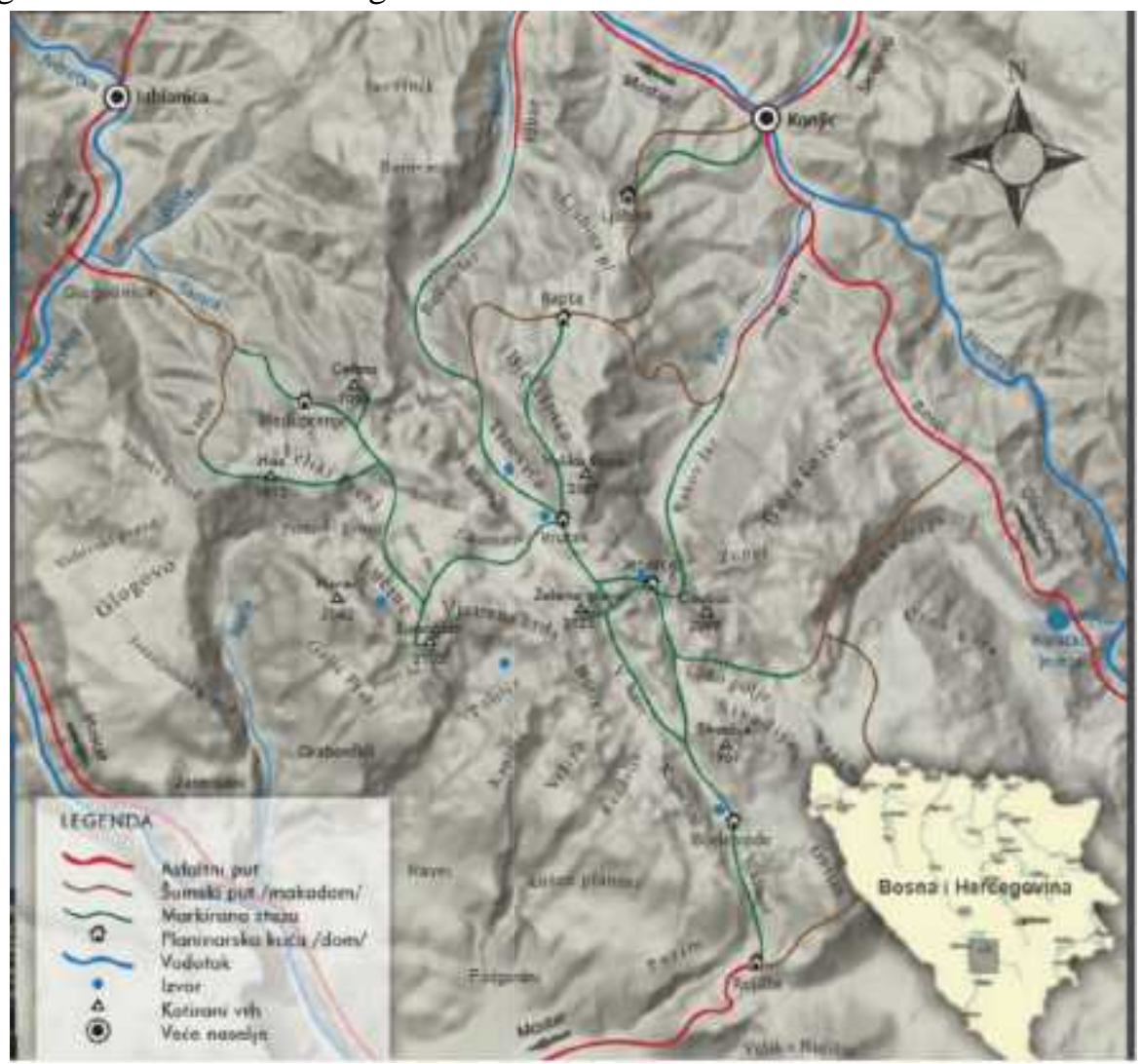

Fig. 1: Geographical position of Prenj mountain

Source: http://www.zeleni-neretva.ba/pdf/Brosura_Prenj.pdf

\section{NATURAL GEOGRAPHICAL TOURISM ATTRACTIONS}

Geomorphological specifications are the basic attribute that makes Prenj recognizable and attractive in every aspect. It is considered as one of the most beautiful and most impressive mountains in whole Bosnia and Herzegovina. Mountaineers say that Prenj is not a usual mountain but kingdom of mountain beauty and Bosnian Himalaya. Prenj deserved this title because of the diversity of mountaineering challenges, endemic species and beautiful peaks.

By its geological composition, Prenj is a complex of Mesozoic formations. Mountainous ridge consists of Triassic dolomites, which dominate in the northern part of the Prenj massif, while the rest of the Veliki Prenj, a central and southern parts, are made up of Jurassic limestones, with the exception of the smaller parts of central Prenj with the Cretaceous limestone. Prenj is distinguished by a special type of limestone dolomitic limestone. 
Prenj presents mosaic of various relief forms. Three levels of relief differ from the altitude: low valley, middle karst and high altitude forms. Two peaks - Taraš (1742 m) and Zubac $(1916 \mathrm{~m})$, ponikva in Jezerci below Tareš and valleys at the northeast part of Prenj - Crno polje, Vlasni do, Velike Bare, Tisovica - represent the most famous tourist destination on the mountain.

Prenj makes a border between the Herzegovina karst towards the south and the wide plateau to the north, whose relief influence specific mountain climate (Varišić, 2012). Mediterranean influences penetrates from the south and cold masses from the north of the continent penetrate through the spacious plateaus and river valleys.

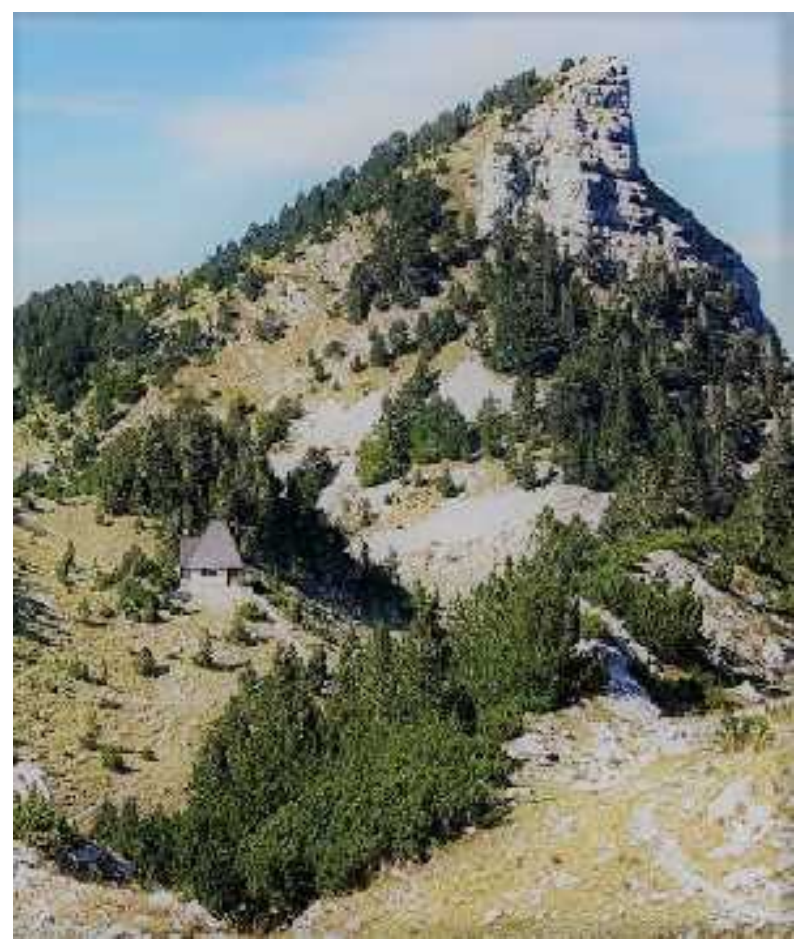

Mountain peaks from the north keep the penetration of cold masses from the interior of the continent, as well as the Mediterranean streams in the interior. According to general climatic conditions, the entire Prenj area is located in a transition zone where moderate continental influences from the north are only slightly stronger than the Mediterranean from the south. Snow cover lasts until May.

Fig. 2: Peak Taraš and mountain hut Jezerce

Undoubtedly, the most famous spring is under Taraš known as Jezerce. There are three springs in the Tisovica valley: Zagon, Novak and Vrutak. Below the Velika Kapa and Borašnica, is the spring of Konjička Bijela. Lake Boračko (402 m) is located in the foothills of Prenj (Fig. 3).

Prenj is a typical representative of the Dinaric ecosystem. The rare and endemic plant species of Prenj and Čvrsnica have attracted researchers since the late 19th century. The importance of this area in the biological and ecological perspective is evidenced by the fact that about 235 plant communities are present in this area, representing about $75 \%$ of plant communities established in Bosnia and Herzegovina (Gafić, Džeko 2009). 


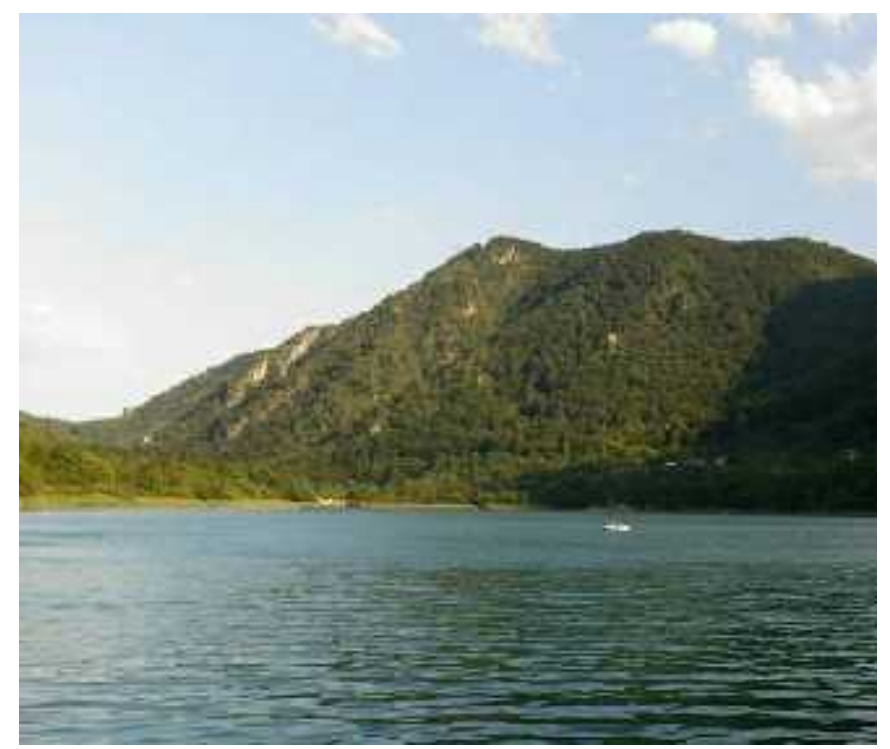

Fig. 3: Boračko lake

Prenj and Čvrsnica are called Herzegovinian endemic development center due to the fact that 308 endemic, subendemic and relicted plant species of the Dinaric area were identified in this area, of which 44 species are the strict endemic areas of Prenj and Čvrsnica, so-called, stenoendemics. In the whole area of Prenj foothills, the most common are beech forests (Fagus sylvatica L.). The most attractive and most impressive are Black pine forests (Pinus nigra J.F.Arnold). Heldreich's Pine or Bosnian pine (Pinus heldreichii), as an endemic and endangered species, is protected by the law. Tourist offer

Landscape contrasts with high green ridge and pointed peaks, beneath which are spacious pastures, beautiful forest landscapes and marked hiking trails, combined with relief and climatic conditions allow the development of various types of tourism:

- Mountain tourism (mountain hiking in Prenj and surrounding mountains);

- Winter mountain tourism (Rujište);

- Mount-biking;

- Rural tourism (accommodation within rural households);

- Fishing tourism (trout);

- Hunting tourism.

The length of sunshine and clean air allow for the development of heliotherapeutic and health tourism. Karst and glacial relief forms and processes represent an attraction for scientific expeditions. Numerous springs, and the wealth of hunting wildlife, enable the development of hunting tourism.

Peaks of Prenj mountain are interesting and attractive for hikers and mountain bikers. Summer is the high season time for hiking on Prenj and some of the most popular trails are: 
- Rujište - Zelena glava;

- Mostarska Bijela - Lupoglav;

- Rujište - Jezerce;

- Rujište - Boračko jezero.

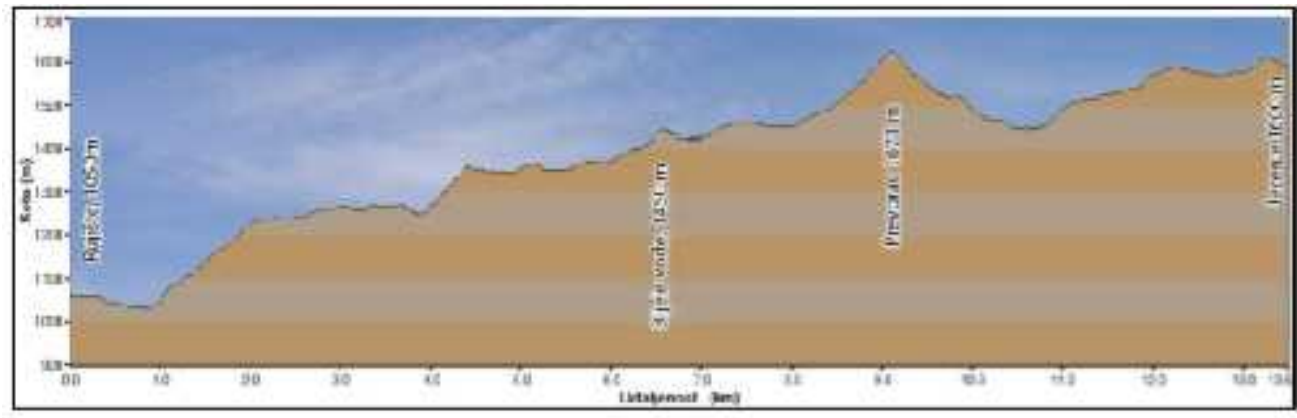

Fig. 4: Profile of mountain path Rujište - Jezerce

There has been a big shift in mountain tourism on Prenj with the development of Via Dinarica; from a localized recreational activity to a tourism product.Via Dinarica is a concept that serves to promote and develop local communities and their role in tourism and agriculture development. This project is an initiative of USAID and UNDP which connects seven countries of the Dinaric Alps mountain range: from Slovenia to northern Albania. Intention of Via Dinarica in Bosnia and Herzegovina is to reduce economic and regional disparities through the promotion of regional tourism attraction especially in less developed regions.

Via Dinarica consists of the three main Trails - Green, Blue and White (Fig. 5). White Trail is the main trail that includes all of the highest peaks of the Dinaric Alps. It's main function is hiking, but it also includes activities like mountain biking and rafting. $\mathrm{BH}-$ W-06 Prenj Mountain is a part of White trail that crosses Prenj from west to south. The trail leads across peaks Zelena Glava $(2155 \mathrm{~m})$ and Otiš $(2093 \mathrm{~m})$, and continues further to Bijele Vode. From Bijele Vode, the trail descends down towards Rujište. 


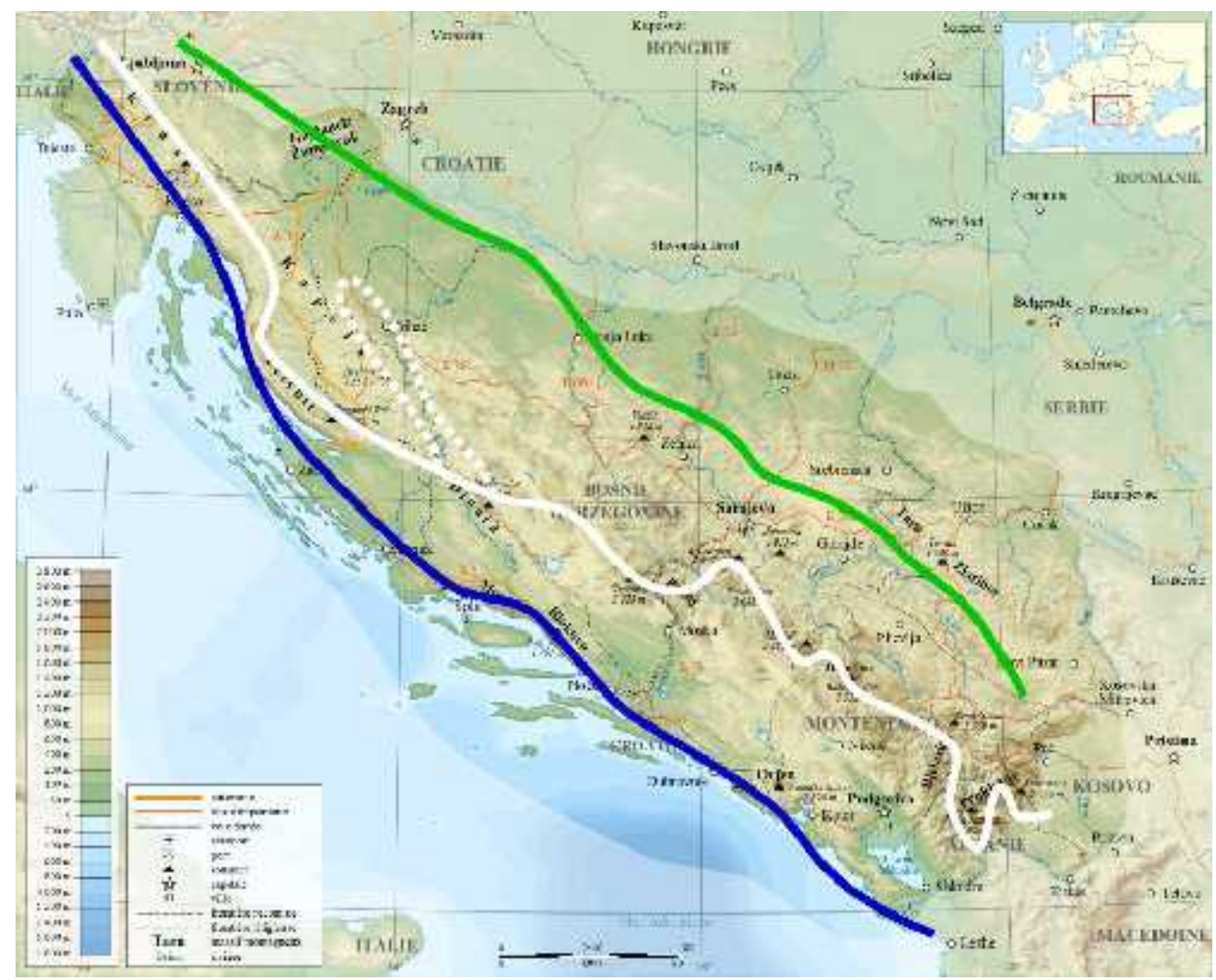

Fig. 5: Via Dinarica trails

Source:http://www.ba.undp.org/content/dam/bosnia_and_herzegovina/img/News/BiH_ Via_Dinarica_trails.jpg

Mountain biking is now one of the most popular tourism activities on Prenj, due to development of Bike park Prenj. According to National Geographic, Prenj was best mountain biking (MTB) adventure destination in 2012.

Bike park Prenj consists of $360 \mathrm{~km}$ of forest roads which have been mapped and marked. These roads are primarily intended for mountain biking but also for other recreational purposes. Info panels show maps of the entire area as well as other useful information. They are located at the following locations:

- Rujište ski resort (in front of Snježna kuća motel);

- Jablanica (at plateau in front of museum);

- Konjic (on the pedestrian path beside the city tunnel);

- Boračko lake (at the entrance).

Mountain sides and snow cover on Prenj, in the colder period of the year represent a huge attraction for the development of ski tourism, especially in the area of Rujište. Rujište is the second built ski resort in the area of Herzegovina-Neretva Canton. From the nearest town of Mostar is only 25 kilometers away. The Rujište ski resort is located on the slopes of Prenj on topographic maps marked as Moljevina (Jahić, 2016). The 
starting point of a relatively short ski path is at the altitude of only 1160 meters, while the end of the path is in the area of the village on the Rujište at an altitude of 1050 meters, with a total denivelation of only 110 meters. The average slope of the ski slope at the Rujište is only $16 \%$, which is classified as a blue ski slope for beginners. The ski resort of the Rujište, considering its character, has only a local tourist significance because the total length of the track is only 700 meters.

In addition, climate characteristics of this area, on average, of 1100 meters above sea level, do not allow skiing season to last longer than three months. Rujište is committed to the development of all-year tourism, with the emphasis on the development of many different types of tourism. There are optimum conditions for the development of a wide range of recreational types of tourism, such as excursions, mountain climbing, mountaineering, adventure and winter skiing. Thanks to the enthusiasm and private investment of the owner of the Snježna kuća on Rujište, a 507-meter ski lift was also renovated, with a capacity of 900 skiers per hour. Night skiing is also available at this ski resort.

\section{CONCLUSION}

In general, it can be said that Prenj mountain represent an extremely important attraction for the development of almost all tourist activities related to mountain areas. The exceptional aesthetic uniqueness of its mountain peaks, hiking and bike trails, mountain lodges in Rujište etc., represent extremely significant tourist attractions, which today are unfortunately still not sufficiently recognised as tourism potentials. Geographical characteristics of Prenj represent an exceptional tourist attraction for the development of tourism. High potential of natural geographical attractions at the recent level of tourist valorisation is extremely poorly used. Problems with relatively weak tourism offer and valorisation should be sought in management, poor selection of ski slopes, extremely poor road communication, lack of significant accommodation facilities and unplanned construction of weekend houses. In the future, it is necessary to improve the governance structure, marketing and promotion activities.

\section{REFERENCES}

1. Charters, T. and Saxon, E. 2007.: Tourism and Mountains: A Practical Guide to Managing the environmental and Social Impacts of Mountain Tours. United Nations Environment Programme. Available at:

http://www.unep.fr/shared/publications/pdf/DTIx0957xPA-MountainsEN.pdf (accessed 27 June 2017).

2. Gafić, M., Džeko, Š. 2009.: Prenj. Sarajevo: Turistička zajednica Kantona Sarajevo.

3. Jahić, H. 2016.: Identifikacija i valorizacija turističko-geografskih sadržaja u turističkom prometu turističke destinacije Hercegovačko-neretvanskog 
kantona, PhD thesis. Department of Geography, Faculty of Science, University of Sarajevo.

4. Lepirica, A. 2008.: Geomorphological characteristics of the massif Prenj. Acta Carsologica 37/2-3, 307-329.

5. Varišić, A. 2012.: Prenj. Konjic: Udruženje za zaštitu okoline - Zeleni Neretva.

6. https://www.outdooractive.com/en/mountain-hike/bosnia-and-herzegovina/viadinarica-bh-w-06-prenj-mountain/17302956/

https://viadinarica.com/en/about/trails

http://www.zeleni-neretva.ba/pdf/Brosura_Prenj.pdf 